\title{
IMP3 wt Allele
}

National Cancer Institute

\section{Source}

National Cancer Institute. IMP3 wt Allele. NCI Thesaurus. Code C114818.

Human IMP3 wild-type allele is located in the vicinity of 15q24 and is approximately $10 \mathrm{~kb}$ in length. This allele, which encodes U3 small nucleolar ribonucleoprotein protein IMP3, is involved in the maturation of ribosomal RNA. 